\title{
Validation of Standard Test Instruments to Improve Mathematical Reasoning Capabilities of Mathematics Student
}

\author{
Hanna Dewi M. Hutabarat ${ }^{1}$, Erlinawaty Simanjuntak ${ }^{2}$, Yasifati $\mathrm{Hia}^{3}$ \\ \{hanahutabarat@unimed.ac.id ${ }^{1}$, erlinawatys@yahoo.co.id ${ }^{2}$, hyasifati@gmail.com\} \\ Department of Mathematics, State University of Medan, Medan, Indonesia ${ }^{1,2,3}$
}

\begin{abstract}
The achievement of learning outcomes must certainly be measured by the presence of tests. A test instrument must represent all the learning outcomes to be obtained. Standard test are tests with a qualitative and quantitative analysis process. The test applied must be a test with a high level of validation. Based on these problems, a standard test instrument will be developed to improve student's mathematical reasoning ability. This research is an educational research and development to form valid essay tests in the form of a test instrument sheet. The preparation of the test instrument is adjusted to the indicators of the achivement based on the IQF curriculum. The validations procedure takes from the define and design steps of a 4-D model viz define, design, develop, and disseminate. Passed the validation phase of the expert, the initial revition, to the empirical validation of the result of the test trials on State University of Medan mathematics student. The outcomes obtained that the standard tests instruments developed are valid.
\end{abstract}

Keywords: The Standard Test Instrument, Mathematical Reasoning Ability, Learning Outcomes

\section{Introduction}

Learning at the tertiary level with the IQF curriculum is learning that focuses on learning outcomes. Learning outcomes are internationalization and accumulation of knowledge, skills, affections and competencies that are achieved through an educational process that is structured and covers a particular field of science / expertise or through work experience. The achievement of learning outcomes must certainly be measured by the presence of tests. The compiled test must cover all indicators of achievement of a competency. Standard tests are tests that have undergone a good qualitative and quantitative analysis process (Balitbang Puspendik Depdiknas, 2007). The test applied must be a test with a high level of validation. The quality of a test of learning outcomes is largely determined by the quality of the items (Kaerudin, 2015).

A test instrument must represent all learning outcomes to be obtained. In the test instrument there are skills to be built. Tri Kodiyono (2018) in his research said that there was a positive relationship between mathematical reasoning and the improvement of students' learning achievement. Mathematical reasoning is simply stated as a person's ability to carry out logical inferences based on existing facts or mathematical statements (Brodie, 2010). This ability is very necessary in the field of algebra. 
Elementary Linear Algebra Course is a subject with material that is directly related to real-world problems and is also used in other subjects in the field of mathematics. Material Linear Equation System (SPL) and Matrix are materials that are closely related to the application of science in the real world. Tests that are used as a standard to test mathematics students already exist but have never been analyzed to see the quality of the test. The development of test instruments is felt to be very necessary to improve the quality of future learning. The development of the test instrument referred to in this study uses the development of test instruments to improve the mathematical reasoning of Medan State University mathematics students.

\section{Rieview Of Literature}

The main text should be written using Times New Roman, 10pt, fully justified. Italics can be used for emphasis and bold typeset should be avoided Some important things that need to be considered before validating a test are how to construct the test so that it meets all the criteria that must be met, in this case related to learning outcomes that are in accordance with the curriculum. Halim (2016) in his research said that the development of test essay instruments is an instrument of High Order Thinking skills. This is why this research uses essay tests as instruments to be able to see clearly mathematical reasoning from mathematics students in studying matrix topic in Elementary Linear Algebra courses.

\subsection{Test Intruments}

The term test instrument is stated as a tool or procedure used in the framework of measurement and assessment. The test is a number of questions given to students to be answered. The test is a consideration of whether or not a competency is achieved. Hadijah et al. (2016) in his research said that students were interested in using cognitive learning outcome test instruments with various variations of questions, so that the criteria for the effectiveness of test instruments were achieved. success of an evaluation activity will also be influenced by the success of evaluators in carrying out evaluation procedures. The procedure in question is the main steps that must be taken in the evaluation activity. What is meant by the evaluator is the educator in planning, compiling and producing a good test instrument, of course based on the things that must be considered in the development of learning outcomes tests.

Mardapi in Widoyoko (2012) states that there are nine steps taken in the development of learning outcomes tests, such as:

1. Compile test specifications. The things that are done when preparing the test specifications are determining the purpose of the test, arranging the grid, selecting the form of the test, and summative tests. This is done to make it easier to write questions and anyone who writes questions will produce a relatively similar level of difficulty.

2. Write test questions. Writing questions is a description of the indicators into questions whose characteristics are in accordance with the details of the grids that have been made.

3. Review test questions. This is done to minimize errors or shortcomings.

4. Conduct test tests. Test trials are conducted as a means of obtaining empirical data about the level of goodness of the questions that have been compiled. 
5. Analyze test items. With the analysis of test items can be known the difficulty level of the item, the distinguishing power, and the effectiveness of the deceiver.

6. Fix the test. This step is usually a test item, which is to fix each item that is still not good.

7. Assemble the test. In assembling questions, things that can affect the validity of the question such as the serial number of the questions, grouping the form of questions, layouts, and so on must be considered because even though the items that have been prepared are good but if any formulation can cause the problem to be bad.

8. Carry out the test. The test is carried out in accordance with the time determined and supervision is needed so that the test is truly done honestly.

9. Interpret test results. The test results produce a quantitative data in the form of a score. This score is then interpreted so that it becomes a value, which is low, medium or high. The high and low values are always associated with the reference. There are two assessment benchmarks that are often used in the world of psychology and education, namely the reference norms and reference criteria.

The things that must be considered in the development of the test according to Arifin (2012), namely: aspects to be measured, parties compiler, purpose of using tests, samples, validity and reliability, administration, how to score, answer keys, raw score table, and interpretation .

\subsection{Mathematical Reasoning Ability}

Mathematical reasoning or commonly known as mathematical reasoning in some literature called mathematical reasoning Brodie (2010) states that "mathematical reasoning is reasoning about and with the object of mathematics". Which can be interpreted by mathematical reasoning is the ability of a person to carry out logical inferences based on facts / statements of existing mathematics.

According to Polya (1954), there are two kinds of reasoning deserves our attention, that are demonstrative reasoning and plausible reasoning. Meanwhile, Lithner (2006) said there are two types of reasoning that students often use in completing math tasks, namely Creative Reasoning (creative reasoning) and Imitative Reasoning (imitative reasoning).

Four criteria of creative reasoning are:

1. Novelty (Novelty). A new set of solutions (for reasoning) are created in problem solving or a series of solutions that have been forgotten, recreated. The answers that only follow the completion procedure are not included in the type of creative reasoning.

2. Flexible (Flexibility). A different approach and adapted for appropriate problem situations.

3. Reasonable (possible). There are arguments that support the choice and implementation of the strategy so that it reinforces the reason that the conclusions given are true and reasonable. In this case, it is not allowed to guess answers.

4. Mathematical (Mathematical foundation). The argument given is in the intrinsic mathematical properties of the components contained in reasoning.

\subsubsection{The Indicator of Reasoning Ability}

According to Sumarmo (Yulia, 2012: 22) reveals that indicators of student has mastered the ability of mathematical reasoning is as follows,

1. Interest logical conclusion; 
2. Give an explanation using pictures, facts, property, existing relationships;

3. Estimating answers and process solutions;

4. Using relationship patterns to analyze, make analogies, generalize, and develop and test expectations;

5. Sending examples of opponents;

6. Submit inference rules, check the validity of arguments, and compile valid arguments;

7. Develop direct evidence, there is no direct evidence, and evidence with mathematical induction.

In addition, indicators of reasoning ability are explained in the Technical Regulation of the Directorate General of Primary and Secondary Education Ministry of Education Number 506 / C / Kep / PP / 2004, describing that indicators of students' reasoning abilities are able to: (Yulia, 2012: 14)

1. Request an accusation

2. Perform mathematical manipulation.

3. Draw conclusions, gather evidence, provide reasons or proof of the truth of the solution.

4. Draw conclusions from the statement.

5. Check the validity of an argument.

6 . Find a pattern or property of mathematical symptoms to make generalizations.

\subsection{Validation}

Azwar in Matondang Z (2009) said that validity has meaning from which the accuracy and accuracy of the measuring instrument (test) in performing its measuring function. Furthermore, he said that a test has a high validity if the tool performs the measuring function appropriately or provides a measurement result according to the purpose of doing the measurement.

In his journal Matondang Z (2009) said that the concept of test validity is divided into three types, namely content validity, construct validity, and empirical validity or criteria validity. The validity of the content of a test tests how much the ability of the test to measure the level of mastery of certain content or material that should be mastered in accordance with the purpose of teaching. Content validity shows the extent to which the test is able to represent or reflect the entire material proportionally. Therefore, the validity of the test is not measured statistically but based on the review of the test grid. While construct validity is carried out based on theoretical studies of theories about the concept of variables to be measured through a logical and careful analysis and comparison process. The third validity, which is empirical validity, which is also called the criteria validity, is the validity of the tests obtained through the results of test tests to the respondents which are equivalent to the respondents to be examined.

In this research, the validation only taken from the expert. Therefore, the validation covered only for the content validity.

\section{Methodology}

Refers to the needs to construct instrument tests, the chosen method to analize is 4-D models. 4-D models is a development models of Thiagarajan, Summel and Summel (1974). 
As the name, in 4-D methods, there are 4 step that given to analize, viz define, design, develop and disseminate.

The steps taken are:

1. Define Stage.

The purpose of this definition is to define and define the needs in preparing the test. Starting with analyzing the objectives and boundaries of the material contained in the indicators of learning achievement. The activities in this stage are initial analysis, student analysis, concept analysis, task analysis and specification of learning objectives.

2. Design phase.

The purpose of this stage is to create a validation sheet and design the test that will be tested.

3. Development phase (develop)

The purpose of the development is to produce a draft standard test instrument. Activities at this stage are: assessment of experts (expert) and readability test, if it is valid then it is continued at the trial stage in large groups to test its validity and reliability.

4. Dissemination Phase (disseminate)

This stage is the final stage in the development of test instruments by carrying out limited implementation of mathematics student.

Figure 1. Research Stage

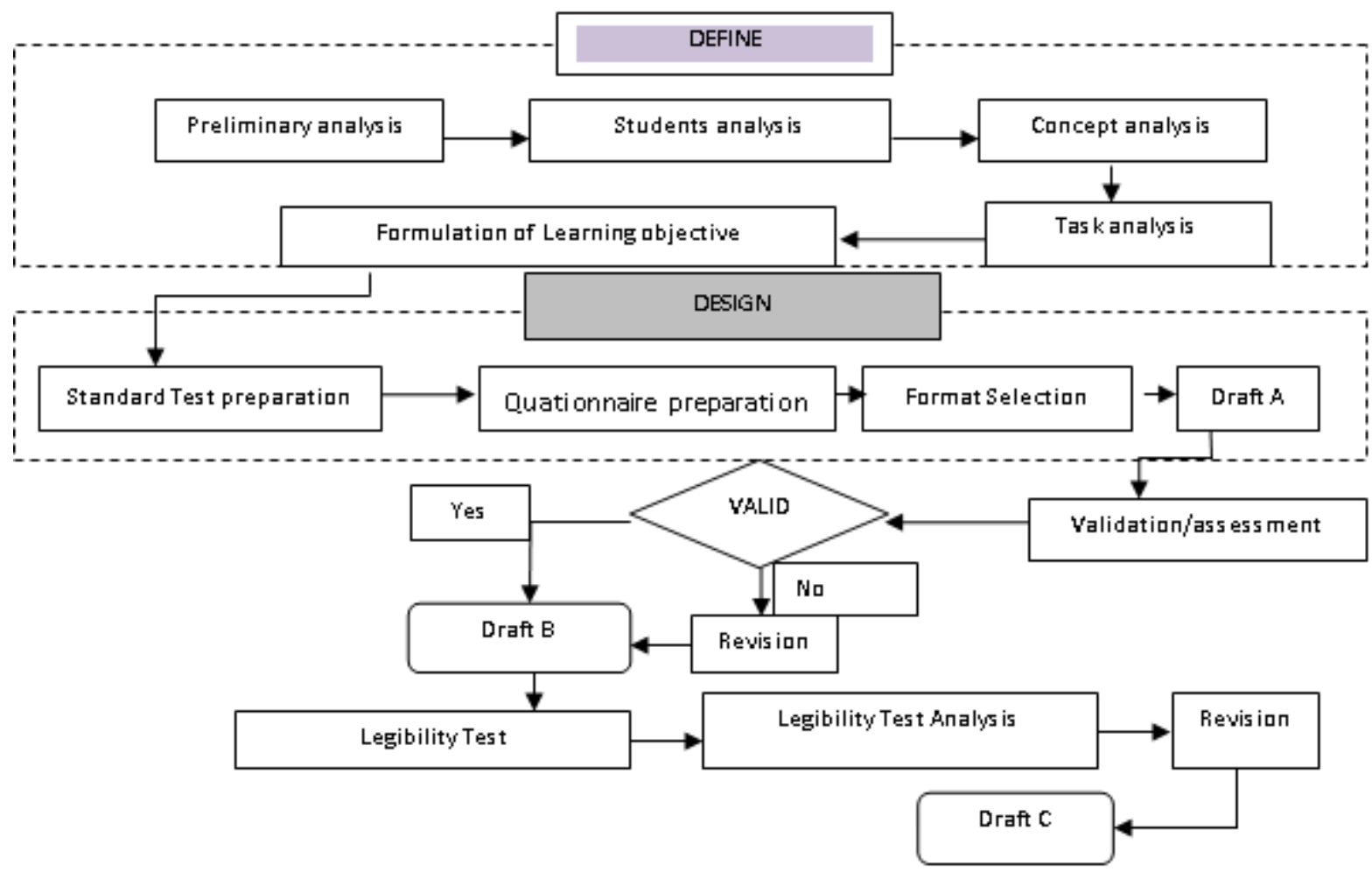




\section{Result And Discusions}

As we can see in the methodology above, the step in which we construct the test from preliminary analyzing to the step where we get the expert validation, is included in first and the second step namely 'Define' and 'Design' step. The outcomes for this steps is a draft of test instrument with revision under the expert validator suggestion.

In this research, the instrument test construct to measure the mathematical reasoning abilities of mathematical student in State University of Medan. The test are prepared in accordance with learning outcomes that we want to achieved based on our IQF curriculum.

\subsection{Indicators of Learning Achievement from Matriks Subject in Elementary of Linear Algebra}

In learning on the topic of the matrix there are 10 learning outcomes to be achieved. The following is a table of student learning outcomes and an indicator of mathematical reasoning abilities on the topic of the matrix.

Table 1: The Students learning outcomes with the indicator of mathematical reasoning abilities.

\begin{tabular}{|c|c|c|}
\hline No. & Learning Outcomes & $\begin{array}{l}\text { Some Kind of Indicator of mathematical } \\
\text { reasoning ability }\end{array}$ \\
\hline 1 & $\begin{array}{l}\text { Understanding that } \\
\text { elementary line } \\
\text { operations (OBE) do } \\
\text { not change the set of } \\
\text { completion of a } \\
\text { system of linear } \\
\text { equations. }\end{array}$ & $\begin{array}{l}\text { 1. Able to provide explanations using the } \\
\text { properties of matrix operations and } \\
\text { elementary line operations. } \\
\text { 2. Analyze the relationship between SPL } \\
\text { and OBE } \\
\text { 3. Directly prove the nature of the OBE. }\end{array}$ \\
\hline 2 & $\begin{array}{l}\text { Able to complete a } \\
\text { system of linear } \\
\text { equations }\end{array}$ & $\begin{array}{l}\text { 1. Able to predict answers that might use } \\
\text { the properties of a linear equation } \\
\text { system } \\
\text { 2. Give a logical answer } \\
\text { 3. Give direct answers correctly }\end{array}$ \\
\hline 3. & $\begin{array}{l}\text { Understanding why } \\
\text { the properties of } \\
\text { matrix operations } \\
\text { apply. }\end{array}$ & $\begin{array}{l}\text { 1. Provide the right reasons according to } \\
\text { the definition and nature of the matrix } \\
\text { 2. Have the right mindset in answering } \\
\text { 3. Complete the system of linear } \\
\text { equations using matrix operations }\end{array}$ \\
\hline 4 & $\begin{array}{l}\text { Give an invers of a } \\
\text { matrix definition }\end{array}$ & $\begin{array}{l}\text { 1. Using the basic properties of the } \\
\text { matrix } \\
\text { 2. Find another way that is better than } \\
\text { the old procedure in finding the } \\
\text { inverse of a matrix } \\
\text { 3. Show the best step to fine the inverse } \\
\text { of a matrix }\end{array}$ \\
\hline
\end{tabular}




\begin{tabular}{|c|c|c|}
\hline 5. & $\begin{array}{l}\text { Recognize that } \mathrm{OBE} \\
\text { is equivalent to } \\
\text { elementary matrix } \\
\text { multiplication }\end{array}$ & $\begin{array}{l}\text { 1. Estimate the results before calculation } \\
\text { 2. Put forward the contradiction of the } \\
\text { statement } \\
\text { 3. Submit a correct argument }\end{array}$ \\
\hline 6 & $\begin{array}{l}\text { Able to calculate the } \\
\text { inverse with OBE }\end{array}$ & $\begin{array}{l}\text { 1. Find short steps with the same process } \\
\text { 2. Indicates the possibility of getting } \\
\text { inverse in many other ways } \\
\text { 3. Provide the right argument for the OBE } \\
\text { step }\end{array}$ \\
\hline 7 & $\begin{array}{l}\text { Understand the } \\
\text { relationship between } \\
\text { the inverse, SPL } \\
\text { solutions and } \\
\text { coefficients }\end{array}$ & $\begin{array}{l}\text { 1. Use inverse properties to make it easier } \\
\text { to identify the characteristics of the } \\
\text { solution from SPL } \\
\text { 2. Using many ways to complete SPL } \\
\text { 3. Knowing all possible solutions from } \\
\text { SPL }\end{array}$ \\
\hline 8. & $\begin{array}{l}\text { Understand the link } \\
\text { between OBE and } \\
\text { changes in } \\
\text { determinant values }\end{array}$ & $\begin{array}{l}\text { 1. Take the right steps when performing } \\
\text { elementary line operations so that the } \\
\text { determinant value does not change. } \\
\text { 2. List changes from each step in OBE } \\
\text { 3. Draw conclusions from the steps that } \\
\text { have been shown }\end{array}$ \\
\hline 9. & $\begin{array}{l}\text { Understand the } \\
\text { characteristics of } \\
\text { matrix determinant }\end{array}$ & $\begin{array}{l}\text { 1. Use the determinant characteristics } \\
\text { as the fastest way to solve a } \\
\text { problem } \\
\text { 2. Find more than one way in solving } \\
\text { a determinant problem. }\end{array}$ \\
\hline 10. & $\begin{array}{l}\text { Understand the } \\
\text { relationship of matrix } \\
\text { determinants to the } \\
\text { existence of a solution } \\
\text { of a linear equation } \\
\text { system }\end{array}$ & $\begin{array}{l}\text { 1. know how to find a matrix determinant } \\
\text { 2. Provide the right argument for the } \\
\text { problem solution using determinant } \\
\text { 3. Estimate the result by the determinant }\end{array}$ \\
\hline
\end{tabular}

From the learning achievement pair and the reasoning ability indicator, a test is prepared so as to produce a valid standard test. The scoring system or score of the test results is also based on the reasoning indicators that are addressed in each test.

Table 2: Example of the answer of tests based on indicators of creative reasoning ability

\begin{tabular}{ll}
\hline Questions and answers & Creative reasoning abilities \\
\hline 1.Show that the following matriks & 1. Novelty \\
has no inverse & 2. Flexibility \\
\hline
\end{tabular}




$$
A=\left[\begin{array}{llll}
0 & a & 0 & 0 \\
b & 0 & c & 0 \\
0 & d & 0 & e \\
0 & 0 & 0 & f
\end{array}\right]
$$

4. Mathematical foundation

The matrix has two columns with the same element. By the defenition of Matrix which have an inverse says that a square matrix Anxn has an inverse if there is a matrix $B$ so that $\mathrm{AB}=\mathrm{BA}=$ In. It can be seen that the inverse matrix must be the same as the identity matrix. Therefore, if above matrix has two same column, it can be ascertained that multiplication of the two matrix is impossible will get the identity matrix. Thats why A has no inverse.

2. Given a system of linear equations as follows

$$
\begin{gathered}
-b x=0 \\
(1-b) y+z=0 \\
y+(1-b) z=0
\end{gathered}
$$

Determine the value of $b$ so that the homogeneous linear equation above has infinitely many solution

The answer could be as follows $\left[\begin{array}{ccc}(-b) & 0 & 0 \\ 0 & (1-b) & 1 \\ 0 & 1 & (1-b)\end{array}\right]\left[\begin{array}{l}x \\ y \\ z\end{array}\right]=\left[\begin{array}{l}0 \\ 0 \\ 0\end{array}\right]$ Observe that if the matrix has 1. Flexibility

2. Possible

infinitely many solution. That

3. Mathematical foundation

implies the matrix not invertible

$\operatorname{det}=0$.

$$
\begin{aligned}
\operatorname{det}=(-b)(-1)^{1+1} & \begin{array}{cc}
1-b & 1 \\
1 & 1-b
\end{array} \mid \\
& =(-b)\left((1-b)^{2}-1\right) \\
& =((-b)(b)(b-2)=0
\end{aligned}
$$

The solution is $b=0$ or $b=2$

From the table above we can see that the test constucted by creative reasoning abilities. 
Table 3: The results of mathematical reasoning instrument validation

\begin{tabular}{lll}
\hline No. & Rated Aspect & Information \\
\hline 1 & Content & Valid \\
2. & Language and writing & Understandable \\
3. & Conclusions & Can be used with minor revisions \\
\hline
\end{tabular}

Table 4 : Validator's Advice

\begin{tabular}{|c|c|c|c|}
\hline No. & Validator & Fault & Suggestion \\
\hline 1. & $\begin{array}{l}\text { First } \\
\text { Validator }\end{array}$ & $\begin{array}{l}\text { The numbers are } \\
\text { too large, take a } \\
\text { long time in } \\
\text { calculations }\end{array}$ & $\begin{array}{l}\text { Improvement to reduce the } \\
\text { number in the calcuation used }\end{array}$ \\
\hline 2. & $\begin{array}{l}\text { Second } \\
\text { Validator }\end{array}$ & $\begin{array}{l}\text { Questions are } \\
\text { unclear }\end{array}$ & $\begin{array}{l}\text { Improvement for questions to } \\
\text { be more directed }\end{array}$ \\
\hline 3. & $\begin{array}{l}\text { Third } \\
\text { Validator }\end{array}$ & $\begin{array}{l}\text { Writing the } \\
\text { question script }\end{array}$ & $\begin{array}{l}\text { Improvement in typing a } \\
\text { question script }\end{array}$ \\
\hline
\end{tabular}

Validated student response questionnaires on tests with aspects based on format, language and content with a total average of 4.25 in good categories. Readability test was conducted twice with the results of questionnaires averaging $60 \%$ and $53.3 \%$. It was seen that the response of student questionnaires was more than $50 \%$ (positive). Now the test has been improved from Draft A to Draft C. All tests have been completed with necessary revision.

\section{CONCLUSIONS}

By analyzing students, analyzing concepts, analyzing assignments, thirty test are arranged with 2 item each indicator as instrument draft A. This grid was validated by expert validators, with minor revisions. By continuing the step with focus on learning outcomes and indicators of students' mathematical reasoning abilities, the valid instrument will become draft B. From The results this test has been stated in a good category with an average of 4,25 and have received a positive response from more than $50 \%$ of student in the legibility test. Thus the valid test is ready to be used as a final tool that produces a test instrument that can improve the mathematical reasoning abilities of State University Of Medan mathematics students. Further more, this research still can be continued by developing test instrument not only by the mathematical reasoning abilities, but also includes the others abilities. 


\section{References}

[1] Arifin, Z.: Evaluasi Pembelajaran Prinsip, Teknik, Prosedur. Bandung: Remaja Rosdakarya (2012)

[2] Brodie,K.: Teaching Mathematical Reasoning in Secondary School Clasroom, New York ; Springer (2010)

[3] Halim.A., Yusrizal, 2016. Development and Implementation of Higher Order Thinking Skills Instruments ini Physics education, Proceedings ICERE 2016

[4] Lithner, J.: A Framework for Analysing Creative and Imitative Mathematical Reasoning. Volume 1 (2006)

[5] Matondang Zulkifli.: Validitas dan reabilitas suatu instrument penelitian, Jurnal Tabularasa PPS Unimed, vol.6 no.1.(2009)

[6] Polya, G.: Mathematics and Plausible Reasoning. Induction and Analogy in Mathematics. Vol.I. New Jersey: Princeton Univesity Press.(1954)

[7] Sastrosudirjo, S.S.: Hubungan Kemampuan Penalaran dan Prestasi Belajar untuk Siswa SMP. Jurnal Kependidikan no.1 Tahun ke 18: IKIP Yogyakarta.(1998)

[8] Sukadijo, G.R.: Logika Dasar Tradisional, Simbolik dan Induktif. Jakarta: Gramedia(1999)

[9] Widoyoko, E. P.: Teknik Penyusunan Instrumen Penelitian. Yogyakarta: Pustaka Pelajar.(2012)

[10] Yulia, Winda.: Implementasi Pembelajaran Matematika dengan Pendekatan Investigasi dalam Meningkatkan Kemampuan Penalaran Matematis Siswa SMP. Skripsi UPI Bandung: Not Publish.(2012) 